\title{
The Role of School Prevention Efforts in Early Marriage in the Ponjong District
}

\author{
* $1^{\text {st }}$ Masruroh \\ Doctoral Program in Community \\ Development \\ Universitas Sebelas Maret \\ Surakarta, Indonesia \\ irfanarvin77@gmail.com
}

\author{
$2^{\text {nd }}$ Soetrisno \\ Faculty of Medicine \\ Universitas Sebelas Maret \\ Surakarta, Indonesia \\ soetrisno_spogk@yahoo.com \\ $4^{\text {th }}$ Sapja Anantanyu \\ Departement of Community \\ Development \\ Universitas Sebelas Maret \\ Surakarta, Indonesia \\ sap_anan@staff.uns.ac.id
}

\author{
$3^{\text {rd }}$ Mahendra Wijaya \\ Faculty of Social and Political Science \\ Universitas Sebelas Maret \\ Surakarta, Indonesia \\ mahendrawijaya@staff.uns.ac.id
}

\begin{abstract}
In 2021-2030 estimated to reach 15.1 million per year in the world will occur before 18 years old. One in ten Indonesian women married under 10 years old. Special Region of Yogyakarta is the one province that still occurred the incidence of the former marriage. Gunungkidul Regency had the highest rate of it when compared with other districts. This study describes the role of schools in preventing former marriage. The research was a descriptive qualitative in January 2020 at the Junior High School 8 Ponjong District of Gunungkidul, Special Region of Yogyakarta. There was 8 head-master for the key informant and 8 students for supporting informant. Collected data with in-depth interviews and documentation studies. Data analysis interactive model of Miles and Huberman. The role of the school to prevent early marriages performed by enhancing the knowledge, supervision by a teacher, and cross-sectoral cooperation. PHC was a related institution instrumental in the prevention of early marriage. A variety of extracurricular activities at school also support to prevent early marriages. The school had an important role in the prevention of early marriage.
\end{abstract}

\section{Keywords - the role of school, prevention, early marriage}

\section{INTRODUCTION}

Former age marriages are marriages in which one or both of the couples are children under the age of 18 . It was without official state registration or approval [1]. In adolescents less than 18 years, including the age of the child and every child must get the widest opportunity to grow and develop optimally [2]

Many parties have made many efforts to protect children. But the number of marriages or former marriages still exists. WHO estimates that around 14.2 million people get married under the age of 18 years between 2011 and 2020. This figure will increase to

15.1 million per year between 2021 and 2030 [3]. In some countries around the world, the number of former marriages is relatively high. India has reached 27 percent of adolescents who are married at 18 [4], while in Ethiopia it has reached 40 percent of adolescent girls who have a former marriage [5]. Whereas in Indonesia, one of ten Indonesian women married before the age of 18[6]. The Special Region of Yogyakarta is in lower-order compared to other provinces in Indonesia. Gunungkidul is the district with the highest number of former marriages. Based on data from the Gunungkidul Religion Office, the Ponjong sub-district is one of the highest districts of early marriage.

The causes of early marriage or child age are because of factors such as low education of women, disparities in age between husband and wife, and the place of residence and culture [7], [8]. The results of other studies also show that, for economic factors, lack of knowledge, and unwanted pregnancies, early marriage factors have been identified [9], [10].

Because of early marriage, among others, children may be deprived of the right to education, play and fulfill their potential, the right to live free from violence and abuse, the right to safety, the right to be protected from exploitation, the right not to be separated from their parents with their wishes [11]. Medical risks that occur in early marriages include high-risk pregnancy and childbirth complications that may increase morbidity in mothers and infants[12]. Women 10-14 years of age appear to have a five-fold higher risk of dying in pregnancy and childbirth than women 20-24 years of age, and global deaths because of abortion are the major causes of death for girls 15-19 years of age [13].

Many parties have attempted to discourage early marriage in the Gunungkidul Regency, one of which is the Regent Regulation on the prevention of early marriage[14]. Implementing the Regent Regulation that the avoidance of early marriage includes multiple stakeholders, both within the community itself and at the stakeholder level. School matters in the prevention of early marriage. Middle-aged adolescents attend junior high school education. Puberty also appears with some symptoms of secondary sex [15].

They felt a sense of attraction to the opposite sex so that many of them already acquainted with dating [16]. The importance of preventing early marriage begins in middle school because there are still a lot of early marriage incidents when they are still in junior high school. Ponjong Subdistrict has 10 junior high schools comprising 4 public 
junior high schools and 6 private junior high schools. Some of these junior high schools have students who have early marriage experience, both public and private.

\section{METHOD}

The study site was in the sub-district of Ponjong, Gunungkidul Regency, Yogyakarta. It comprises 4 public schools and 4 private schools. The number of research informants is 8 principals and 8 junior high school students. Retrieval of research data with research informant interviews and study reports by analyzing records of different early marriage cases in junior high school. Work performed in January 2020.

The location of the study is determined based on data collected from the Gunungkidul Regency Ministry of Religion, with the highest percentage of early marriages. Then continue with the decision of the junior high school (SMP) which would be used to identify the research informant. The selection of SMPs with inclusion criteria includes schools that are still active through teaching and learning activities and have active students from Grade 7 to Grade 9 with a minimum of 30 students and will be a place of research. The major criteria for informants in this study were that they served as principals, had served as principals for at least one year, and would be research informants. Whereas helping informants with the requirements of students who have menarchal/ wet dreams, are not new and can become research informants.

The selection of research locations with the help of the Head of the Middle School Department of Education, Youth, and Sport, Gunungkidul Regency, Yogyakarta. As a result, eight secondary schools, comprising four public junior high schools and four private junior high schools, were obtained from data validation and inclusion criteria. Twenty- five percent of schools had an early marriage for out-of-marriage pregnancy.

Characteristics of the key informants in this study are dominant with 75 percent male and only 25 percent female. Education S2 37.5 percent, education S1 50 percent, and education D1 12.5 percent. The period of the school principal at the study site is 1-3 years 50 percent and > 3 years 50 percent. Age 20-30 years 12.5 percent $31-40$ years 12.5

percent 41-50 years 12.5 percent and 51-60 years 62.5 percent respectively. Whereas for all informants in middle adolescence $13-15$ years, in the seventh grade 12.5 percent in the eighth grade 50 percent and the ninth grade 37.5 percent. The entire person experienced menarche and said he was attracted to the opposite sex/dating.

Following the interview, the documentation study also included the Regent Regulations on Preventing Early Marriage, the Joint Declaration on Preventing Early Marriage and the School Registry of the BK Teachers, which recorded various cases of female students, in particular in early marriage.

\section{RESULT}

Based on the results of interviews conducted, school efforts in efforts to prevent early marriage

\section{A. Increased knowledge about reproductive health}

The results of interviews conducted with key informants in eight junior high schools in the Ponjong District show that all teachers involved in this effort by increasing knowledge about reproductive health in each subject. The most important role in increasing knowledge about reproductive health, especially regarding former marriage, is the science teacher and counseling guidance teacher. Like the following interview excerpt:

"... E, that is from a science teacher, and every subject that is related to reproduction is shown and played videos about dangerous things for female and male students..." ("M," Head of SMPN 2 Junior High School, Ponjong)

"... if the content of the lessons from our science is conveyed, then from all the lessons, if there was a time the teacher would remind about health, good health food, the importance of maintaining health..." ("AY," Head of Baitul Quran Junior High School, Ponjong)

\section{B. Supervision and help of students}

Besides increasing knowledge, schools also provide supervision and help to students who experience certain problems at school. The form of this help includes the conduct of a home visit by the home-room teacher and the guidance and advice of the teacher. The home visit aims to find out the condition of the students at home so that the assistant is optimal because it involves the parents/guardians of the students. The following are excerpts from the interview:

"... Yes, besides the briefing, there is also a meeting and then a home visit..." ('WBR' Head of SMPN 4 Ponjong)

If the form of monitoring routinely pays attention to students who are deemed to be breaching the Code of Conduct, they take immediate action. For example, monitoring and controlling the usage of cellphones. Here are several extracts from the interview.

"... in schools, if teachers need it, it is acceptable, but if you bring it every day, you should not bring it, if someone brings it, give it to the mayor or the administration..." ('M' Head of SMPN 2 Ponjong)

This statement is supported by the results of interviews with students:

"... Inspection is not rare, just if someone brings a cellphone and is found to carry the cellphone immediately without inspection ..."

\section{Extracurricular activities}

After introducing teaching and learning programs, all secondary schools in the Ponjong sub-district carry out extracurricular activities. This extracurricular activity is primarily for the seventh and eighth graders, as the emphasis for the ninth graders has been on their studies to help the success of the national exams. There are extracurricular courses that are compulsory and optional, according to their interests and talents. With the involvement of extracurriculars, they can refine their talents and help them fill their free time with positive things so that they do not fall into negative things, particularly relationships with the opposite sex. As an excerpt from the following interview : 
"... Extras activity are various, there is extra mandatory, extra mandatory is scouted, then there are extra choices, extra choices are Pencak silat, volley, and futsal, we have what, what is superior in this case is Pencak silat and volley, because several times we can produce awards, both at the sub-district, district and even provincial level." ("J," Head of Junior High School, Ponjong)

"... Scout activities every Saturday afternoon, Taekwondo Thursday afternoon - before sunset (mandatory). Archery and horse riding, swimming, just Sunday. If you shoot Wednesday. If swimming is the same as riding on Sunday, the same as futsal." ("AY," Deputy Principal of Baitul Quran Middle School, Ponjong)

\section{Cross-sectoral cooperation}

Besides internal school efforts, efforts to prevent early marriages. They are also being made in collaboration with cross-sectoral organizations. Cross-sectoral coordination is taking place in Puskesmas (health primary care), KUA (Religious Affairs office), and the police. Although this has not been done periodically, they cooperate on certain conditions to prevent teenagers from getting older, including preventing former marriage. Puskesmas (health primary care) is the most important part of this cross-sectoral collaboration, as some Puskesmas programs also involve immature people, especially in schools. The following are the extracts of the interview:

"... Yes, for the implementation, we made an MOU with a puskesmas with KUA with the police with the environmental service.." ("P," Head of Junior High School 1 Ponjong)

It also supported the statement from the following student interviews:

"... From health education from schools or villages

...." ("S" Junior High School 1 student, Ponjong).

\section{DISCUSSION}

Teenagers are the moment that someone grows up or becomes an adult. Puberty is a disorder in which an infant experiences physical, psychological, and sexual changes. Growth and development take place quickly and the first menstruation (menarche) is marked in women, while in man's wet dreams and the second sex development period of 2-3 years are marked, and the role of the genitals is very prominent in physical development[15],[17].

Teenagers at an early age have felt very close to their peers, want to be free with no rules, and pay attention to their physical condition and abstract thinking [18]. Adolescence is also the beginning of learning to date and starting to engage in sexual activity. The reasons

teenagers have sexual relations out of love or are similarly eager and curious, so it is easy for a youthful woman to give up her honor [19]. It is not surprising that there are many cases of early marriage because they begin by falling in love and then dating and finally having sexual relationships outside of marriage, resulting in unwanted pregnancy [10], [20].
Some teenagers are often dating only because of the influence of friends or because teens feel the need for friends to share and experience physical attraction, but there is also the presence of friends with peers who can contribute positively to student motivation [21].

Adolescent friendships can occur in or around the school environment. If they are at home, the role of parents is very dominant in the form of a teenager's personality [22], [23]. Whereas while they are in school, it has become the role and responsibility of educators and non-educators in the school setting. Findings from interviews and documentation studies in the last five years showcase early marriage in junior high schools in the Ponjong sub-district as much as 25 percent. The school has therefore made some efforts to prevent early marriage by increasing the knowledge of its students.

We have gained increased knowledge of reproductive health from entering the junior high school during the school orientation/admission activities of fresh students. This knowledge is very important because, with sufficient knowledge of curiosity about everything for a teenager, especially about sexuality, sufficient knowledge can be directed so it is expected to change behavior that is not appropriate and to find out all the intact information for reproductive health [24]- [27].

Implementation of increased knowledge about reproductive health at school is not only the responsibility of the principal but is the responsibility of all educators and non- educators, educators, in this case, teachers, especially guidance and counseling (BK) teachers, homeroom teachers and natural science teachers. Especially for BK teachers, some schools provide separate hours for class and one of them is about reproductive health. Whereas subject teachers provide knowledge about reproductive health following existing norms on the sidelines of the subjects, they do every day [28], [29].

Besides increasing knowledge, supervision and help are also provided by teachers, in particular BK teachers. One example of this supervision is regulations on orderly school enforcement and the use of devices, in particular cell phones at school. The influence of social media is very worrying, especially for adolescents. The result is not all negative, but it can also have a positive effect. However, given the psychological state of adolescents who are still very dysfunctional, cell phone surveillance is carried out to prevent negative influences, particularly those related to juvenile delinquency and anything related to pornography[30]-[33].

BK (Guidance and Counseling) teachers and other teachers not only provide help in schools but also carry out home visits. [34]. It is done so that students can be monitored for daily life not only within the school but also in the condition of the environment of his home/family and home-visit is very supportive so that a teacher gets accurate information about the problems faced by students [35]. This home visit can also motivate their students to be more enthusiastic in learning [36].

Conduct cross-sectoral cooperation with relevant agencies in efforts to prevent early marriage. They have established some of this collaboration with the Office for Religious Affairs, the Police, and the Puskesmas[37]. Among 
the three agencies that play the most important role in preventing early marriage is Puskesmas because several programs in Puskesmas are directly related to adolescent reproductive health, some activities that have been carried out, among others, concerning maturing the age of marriage, the prevention of sexually transmitted diseases and the formation of peer counselors [38]-[41].

Prevent early marriage through extracurricular activities at school. This activity is a non-formal activity carried out by students, especially in junior high schools, with the primary aim of enabling students to grow their talents and interests and other skills outside academic activities. This extracurricular activity can have a positive effect on students who pursue it, among others, by increasing academic trust and graduation[42],[43]. Other research also states that participation in extracurricular activities can improve students' social-emotional skills [44]. Various positive effects of the effects of extracurricular activities will form a teenager who has its character and will indirectly avoid these teenagers from negative things, one of which can lead to early marriage.

Gunung Kidul Regent Regulation No 36 of 2015 provides that the prevention of early marriage is the responsibility of all elements of society. The purpose of the Regent Regulation Decision is to take a strategic step towards supporting and creating a family confident of the warohmah mawadah. And preparing a mature person to live in the household ark. More optimal socialization is still required, however, so it can be transmitted to the wider community, particularly to those who live far away in remote villages[45],[46].

According to child protection regulations, the age of the infant is 18 years. Each school's joint declaration on childfriendly marriage, to prevent early marriage, is part of the application of child protection legislation and can provide for children's rights. Children's-friendly schools are required to protect and provide services that guarantee and protect children, particularly those attending school in educational units [47]- [49]

\section{CONCLUSION}

The role of junior high schools in the sub-district of Ponjong in efforts to prevent early marriage is to increase knowledge of reproductive health, supervision, and help by all teachers through implementing child-friendly schools and home visits. Optimization of extracurricular activities in schools Collaboration across sectors with the KUA (Religious Affairs Office), the Police Sector, and the

Puskesmas (Health Primary Care) to prevent early marriages and to carry out since the beginning of the school orientation period.

Increased knowledge of reproductive health through workshops and training for health practitioners and noneducators, so they do not confine the primary source of information at school from BK (Guidance \& Counseling) teachers and science subject teachers.

\section{REFERENCES}

[1] Evenhius, "Just Married, Just a Child." Plan International Australia, p. 26,2014
[2] Undang-undang Republik Indonesia No 23 Tahun 2002 Tentang Perlindungan Anak. 2002

[3] United Nations Population Fund for Population Activities, "Marrying too young End Child Marriage." The United Nations Population Fund New York, USA, New York, 2012.

[4] I. International Institute for Population Sciences (IIPS), "National Family Health Survey (NFHS-4), 2015-2016.” IIPS, Mumbai, India, 2017.

[5] Central Statistical Agency (CSA) Ethiopia and ICF, "Ethiopia Demographic and Health Survey 2016." CSA and ICF, Addis Ababa, Ethiopia and Rockville, Maryland, 2016.

[6] Indonesia Ministry of National Development Planning and the United Nations hildren's Fund, "SDGs Baseline report on children in Indonesia.” Jakarta, 2017

[7] İ. Yüksel-Kaptanoğlu and B. A. Ergöçmen, "Early Marriage: Trends in Turkey, 1978-2008," J. Fam. Issues, vol. 35, no. 12, pp. 1707$1724,2014$.

[8] M. Nasrullah, R. Zakar, and M. Z. Zakar, "Child marriage and its associations with controlling behaviors and spousal violence against adolescent and young women in Pakistan," J. Adolesc. Heal., vol. 55, no. 6, pp. 804-809, 2014.

[9] G. Workineh, S.; Kibretb, G.D., \& Degu, "Determinants of Early Marriage among Female Children in Sinan District, Northwest Ethiopia - ProQuest," Heal. Sci. J., pp. 1-7, 2015.

[10] Judiasih, Perkawinan Bawah Umur di Indonesia. Bandung: Refika Aditama, 2018

[11] "Undang-undang Republik Indonesia No 35 Tahun 2014 Tentang Perubahan atas Undang-Undang No23 Tahun 2002 Tentang Perlindungan Anak.” Jakarta, 2014.

[12] D. E. Ratnasari, "6 Penyebab Kematian Ibu Melahirkan Versi AIPI," CNN Indonesia, Oct-2018.

[13] WHO, World Health Statistics 2014. Genewa: WHO Press, 2014

[14] "Peraturan Bupati Kabupaten Gunungkidul No 36 Tahun 2015. Tentang Pencegahan Pernikahan Dini. Gunungkidul Yogyakarta." 2015.

[15] Ali dan Asrori, Psikologi Remaja: Perkembangan Peserta Didik, 13th ed. Bumi Aksara, 2018.

[16] Sarwono, Teori-teori Psikologi Sosial, 19th ed. Jakarta: Raja Grafindo Perkasa, 2017.

[17] Kusmiran, Kesehatan Reproduksi Remaja. Yogyakarta: Salemba Medika, 2013

[18] Widyastuti, Rahmawati, and Purnamaningrum, Kesehatan Reproduksi, 5th ed. Yogyakarta: Fitramaya, 2014.

[19] Papalia, Old, and Feldman, Human Development (Psikologi Perkembangan), Bag V-IX. Jakarta, 2008.

[20] J. E. Mpilambo, S. Susumanappunni, O. Kanayo, and

N. Stiegler, "Determinants of early marriage among young women in Democratic Republic of Congo," J. Soc. Sci., vol. 52, no. 1-3, pp. 82-91, 2017

[21] A. R. Mutiara and S. Mayasari, "Hubungan Antara Interaksi Teman Sebaya Dengan Prestasi Belajar The Correlation Between Peer Group Interaction With Learning Achievement." FKIP Universitas Lampung, Bandar Lampung, 2018.

[22] F. Madeni, S. Horiuchi, and M. Iida, "Evaluation of a reproductive health awareness program for adolescence in urban Tanzania-A quasiexperimental pre-test post-test research," Reprod. Health, vol. 8, no. 1, pp. 1-9, 2011.

[23] Deepshika and S. Bhanot, "Role of Family Environment on Socioemotional Adjustment of Adolescent Girls in Rural Areas of Eastern Uttar Pradesh," J. Psychol., vol. 2, no. 1, pp. 53-56, 2011.

[24] N. Joseph, "Effectiveness of Structured Teaching Program on Knowledge Regarding Health Consequences of Early Marriage and Late Marriage," vol. 2, no. June, 2017.

[25] V. Vandana, K. Simarjeet, and S. Manisha, "Assessment of Knowledge and Attitude of School Girls Regarding Early Marriage and Early Pregnancy," Int. J. Heal. Sci. Res., vol. 7, no. April, pp. 297-302, 2017. 
[26] H. T. Yang et al., "Status of reproductive health knowledge for junior high school students in Guangzhou city," J. Reprod. Contracept., vol. 27, no. 1, pp. 41-49, 2016.

[27] N. Rajapaksa-Hewageegana, H. Piercy, S. Salway, and S. Samarage, "Sexual and reproductive knowledge, attitudes and behaviours in a school going population of Sri Lankan adolescents," Sex. Reprod. Healthc., vol. 6, no. 1, pp. 3-8, 2015.

[28] M. Delprato, K. Akyeampong, and M. Dunne, "Intergenerational Education Effects of Early Marriage in Sub-Saharan Africa," World Dev., vol. 91, pp. 173-192, 2017.

[29] N. C. Ricard and L. G. Pelletier, "Dropping out of high school: The role of parent and teacher self- determination support, reciprocal friendships and academic motivation," Contemp. Educ. Psychol., vol. 44-45, pp. 32-40, 2016.

[30] D. Ratnasari and Haryanto Haryanto, "Analysis of Utilization of Gadgets as Effective Learning Media in Innovation Education to improve Student Learning Achievement," International Conference on Meaningful Education, KnE Social Sciences, vol. 2019. pp. 460467, 2019.

[31] A. Hudaya, "Pengaruh Gadget Terhadap Sikap Disiplin Dan Minat Belajar Peserta Didik," vol. 4, no. 2, pp. 86-97, 2018.

[32] Frahasini, T. Marhaeni, P. Astuti, and H. T. Atmaja, "The Impact of The Use of Gadgets in School of School Age Towards Children $\hat{a}^{\mathrm{TM}}{ }_{\mathrm{s}}$ Social Behavior in Semata Village," J. Educ. Soc. Stud., vol. 7, no. 2, pp. 161-168, 2018.

[33] Nurmalasari and D. Wulandari, "Pengaruh Penggunaan Gadget Terhadap Tingkat Prestasi that are easy to carry anywhere for," Ilmu Pengetah. Dan Teknol. Komput., vol. 3, no. 2, pp. 1-8, 2018.

[34] H. Aziza, M. A. Yusuf, and I. Sukmawati, "Peran guru bimbingan dan konseling dalam pelaksanaan kegiatan kunjungan rumah pada SMP negeri di kota padang," J. Ilm. Konseling, vol. 2, no. 2 September 2013, pp. 1-6, 2013.

[35] P. G. Handayani and H. Hidayat, "Pentingnya pelaksanaan home visit oleh guru bimbingan dan konseling," in Jambore Konselor, 2017, vol. 3, pp. 168-177.

[36] H. Amalia, "Implementasi Home Visit dalam Upaya Meningkatkan Pembelajaran PAI di SDIT al-Azhar Kediri," Didakt. Relig., vol. 4 no. 1, pp. 77-106, 2016

[37] Utami and Satriyandari, "Fenomena Pergeseran Budaya dengan Trend Pernikahan Dini di Kabupaten Sleman D.I Yogyakarta," $J$. Kebidanan, vol. 8, no. 2, pp. 105-114, 2019.

[38] S. Achora, G. Thupayagale-Tshweneagae, O. A. Akpor, and Y. J. S. Mashalla, "Perceptions of adolescents and teachers on school-based sexuality education in rural primary schools in Uganda," Sex. Reprod. Healthc., vol. 17, no. October 2017, pp. 12-18, 2018.

[39] N. L. K. A. Arsani, N. nyoman M. Agustini, and I Ketut Indra Purnomo, "Peranan Program Pkpr (Pelayanan Kesehatan Peduli Remaja) Terhadap Kesehatan Reproduksi Remaja Di Kecamatan Buleleng," J. Ilmu Sos. dan Hum., vol. 2, no. 1, pp. 129-137, 2013.

[40] L. Falatansah and S. Indarjo, "Perbandingan Program Pelayanan Krr Oleh Puskesmas Yang Di Wilayah Kerjanya Terdapat Lokalisasi Dan Yang Tidak Terdapat Lokalisasi," Public Heal. Perspect. J., vol. 1, no. 1, pp. 68-77, 2016.

[41] P. E. Pesiwarissa, S. T. Messakh, and B. Panuntun, "Gambaran Implementasi Program Kesehatan Reproduksi Remaja di Puskesmas Getasan," J. Keperawatan Respati Yogyakarta, vol. 6, no. 2, p. 570, 2019.

[42] A. Antovska and B. Kostov, "Teachers, students and extracurricular activities in primary education," Int. J. Cogn. Res. Sci. Eng. Educ., vol. 4, no. 1, pp. 49-54, 2016. . Balyer and Y. Gunduz, "Effects of Structured Extracurricular Facilities on Students' Academic and Social Development," Procedia - Soc. Behav. Sci., vol. 46, pp. 48034807, 2012

[43] A. Balyer and Y. Gunduz, "Effects of Structured Extracurricular Facilities on Students' Academic and Social Development," Procedia - Soc. Behav. Sci., vol. 46, pp. 4803-4807, 2012.

[44] W. Carbonaro and E. Maloney, "Extracurricular Activities and Student Outcomes in Elementary and Middle School: Causal Effects or Self-selection?," Socius Sociol. Res. a Dyn. World, vol. 5, p. $237802311984549,2019$.

[45] A. B. Wahyudi, "Implementasi Peraturan Bupati Gunungkidul Nomor 36 Tahun 2015 Tentang Pencegahan Perkawinan pada Usia Anak," Universitas Islam Negeri, 2017.

[46] R. Wagianto, "Urgensi Pencegahan Perkawinan Pada Usia Anak Dalam Peraturan Bupati Gunungkidul Nomor 36 Tahun 2015 ( Perspektif Maqa < S \{ Id Asy-Syari < Ah ), "Universitas Islam Negeri Sunan Kalijaga, 2018.

[47] Z. Slam, "Education nonvioelence through child friendly school," J. Educ. Muslim Soc., vol. 3, no. 2, pp. 186-204, 2016.

[48] Subur, M. N. Qosim, and I. Nugroho, "Implementasi sekolah ramah anak dalam membentuk budaya sekolah di sdn geger tegalrejo 1,2,3," 2015, no. January, pp. 353-357.

[49] S. Febriantina and R. Wijayanti, "Preparing Child- Friendly School Management," Econosains J. Online Ekon. dan Pendidik., vol. 16, no. 1, pp. 76-83, 2018. 